\title{
Impact of sex and gender on COVID-19 outcomes in Europe
}

\author{
Catherine Gebhard ${ }^{1,2,3^{*}+} \mathbb{D}$, Vera Regitz-Zagrosek ${ }^{4,5,6+}$, Hannelore K. Neuhauser ${ }^{6,7}$, Rosemary Morgan ${ }^{8}$ and
} Sabra L. Klein ${ }^{9}$

\begin{abstract}
Background: Emerging evidence from China suggests that coronavirus disease 2019 (COVID-19) is deadlier for infected men than women with a $2.8 \%$ fatality rate being reported in Chinese men versus $1.7 \%$ in women. Further, sex-disaggregated data for COVID-19 in several European countries show a similar number of cases between the sexes, but more severe outcomes in aged men. Case fatality is highest in men with pre-existing cardiovascular conditions. The mechanisms accounting for the reduced case fatality rate in women are currently unclear but may offer potential to develop novel risk stratification tools and therapeutic options for women and men.

Content: The present review summarizes latest clinical and epidemiological evidence for gender and sex differences in COVID-19 from Europe and China. We discuss potential sex-specific mechanisms modulating the course of disease, such as hormone-regulated expression of genes encoding for the severe acute respiratory syndrome coronavirus 2 (SARS-CoV2) entry receptors angiotensin converting enzyme (ACE) 2 receptor and TMPRSS2 as well as sex hormone-driven innate and adaptive immune responses and immunoaging. Finally, we elucidate the impact of gender-specific lifestyle, health behavior, psychological stress, and socioeconomic conditions on COVID19 and discuss sex specific aspects of antiviral therapies.
\end{abstract}

Conclusion: The sex and gender disparities observed in COVID-19 vulnerability emphasize the need to better understand the impact of sex and gender on incidence and case fatality of the disease and to tailor treatment according to sex and gender. The ongoing and planned prophylactic and therapeutic treatment studies must include prospective sex- and gender-sensitive analyses.

Keywords: Gender, Sex, COVID-19, Renin angiotensin aldosterone system, Immune system

\section{Introduction}

In December 2019, a novel $\beta$-coronavirus, now designated SARS-CoV2 (severe acute respiratory syndrome coronavirus 2), was identified as the cause of an outbreak of acute respiratory illness in Wuhan City, China [1]. SARS-CoV2 causes severe respiratory disease,

\footnotetext{
* Correspondence: Catherine.gebhard@usz.ch

${ }^{\dagger}$ Catherine Gebhard and Vera Regitz-Zagrosek contributed equally to this work.

'Department of Nuclear Medicine, University Hospital Zurich, Raemistrasse 100, 8091 Zurich, Switzerland

${ }^{2}$ Center for Molecular Cardiology, University of Zurich, Schlieren, Switzerland Full list of author information is available at the end of the article
}

termed coronavirus disease 2019 (COVID-19), which represents its most frequent lethal complication. Since its outbreak, SARS-CoV2 has spread to 196 countries and has been declared a pandemic by the World Health Organization (WHO) on March 11, 2020 [2, 3]. It has caused over 2 million confirmed infections with over 130,000 deaths worldwide (as of April 15, 2020), of which two-thirds have occurred in Europe [4]. To date, no specific antiviral treatment for SARS-CoV2 exists, but a number of investigational agents are currently being explored including remdesivir, lopinavir-ritonavir, a combined protease inhibitor, chloroquine/hydroxychloroquine, colchicine, and tocilizumab, an IL-6 inhibitor

(c) The Author(s). 2020 Open Access This article is licensed under a Creative Commons Attribution 4.0 International License which permits use, sharing, adaptation, distribution and reproduction in any medium or format, as long as you give appropriate credit to the original author(s) and the source, provide a link to the Creative Commons licence, and indicate if changes were made. The images or other third party material in this article are included in the article's Creative Commons licence, unless indicated otherwise in a credit line to the material. If material is not included in the article's Creative Commons licence and your intended use is not permitted by statutory regulation or exceeds the permitted use, you will need to obtain permission directly from the copyright holder. To view a copy of this licence, visit http://creativecommons.org/licenses/by/4.0/ The Creative Commons Public Domain Dedication waiver (http://creativecommons.org/publicdomain/zero/1.0/) applies to the data made available in this article, unless otherwise stated in a credit line to the data. 
[5]. The worldwide case fatality rate of $3.4 \%$ of COVID19 now exceeds that from seasonal influenza [2]. Death results from acute respiratory distress syndrome (ARDS), acute respiratory failure, coagulopathy, septic shock, and metabolic acidosis [6]. Cardiovascular complications of COVID-19 comprise arrhythmias, acute cardiac injury, and shock, and have been reported in $7-17 \%$ of hospitalized patients [7]. In Italy, the estimated case fatality rate was $7.2 \%$ [8], while it was $0.9 \%$ in South Korea [3] and $2.3 \%$ in China [6]. Case fatality is highest in those aged > 80 years (14.8\% in China, $20.2 \%$ in Italy) and in patients with pre-existing conditions including cardiovascular disease, diabetes mellitus, chronic respiratory disease, hypertension, and cancer [6, 9]. Among all comorbidities, cardiovascular disease in the elderly was most consistently associated with adverse outcomes, as a case fatality rate of $10.5 \%$ has been reported in this high-risk population [6].

\section{Sex differences in COVID-19 epidemiology and case fatality}

First reports from China have pointed to a sex imbalance with regard to detected cases and case fatality rate of COVID-19 [1, 10, 11]. However, to date only few reports have addressed the sex disproportion in COVID19 incidence and disease course and a thorough analysis of underlying causes is currently lacking [12-15]. As the disease has spread across multiple continents, the Global Health 50/50 research initiative presented an impressive overview of sex-disaggregated data from countries worldwide clearly demonstrating similar numbers of cases in women and men, but an increased case fatality in men [16] (Fig. 1). Nevertheless, sex-disaggregated data are still not provided by all countries, the interaction of sex and age is usually not visible in the public databases, and number of cases and case fatality vary significantly by region. To obtain a detailed European view and to cover these aspects, we collected latest epidemiological data (as of April 1st) on confirmed COVID-19 cases in Italy, China, Spain, France, Germany, and Switzerland [17-22] across multiple disease metrics including recently published hospitalization and intensive care (ICU) admission data. Similar to global statistics, these reports show no major sex differences in the absolute number of confirmed COVID-19 cases in those countries where sex-disaggregated data were available (Fig. 2). However, equal absolute numbers of cases in women and men may point towards a higher incidence in men in the older age groups (i.e., proportions of COVID-19 diagnosed older men among men in that age group) since older men are fewer in absolute numbers than older women due to their shorter life expectancy. In fact, reports from Switzerland and Germany have recently reported incidence rates (cases per 100,000 inhabitants by age and sex), which confirm an increased disease incidence in men $>60$ years, $[21,22]$. In detail, the disease incidence in men per 100,000 Swiss inhabitants in the age groups of 60-69 years, 70-79 years, and $80+$ years was 267, 281, and 477, respectively, as of March 30. The numbers reported in men exceeded the ones reported in

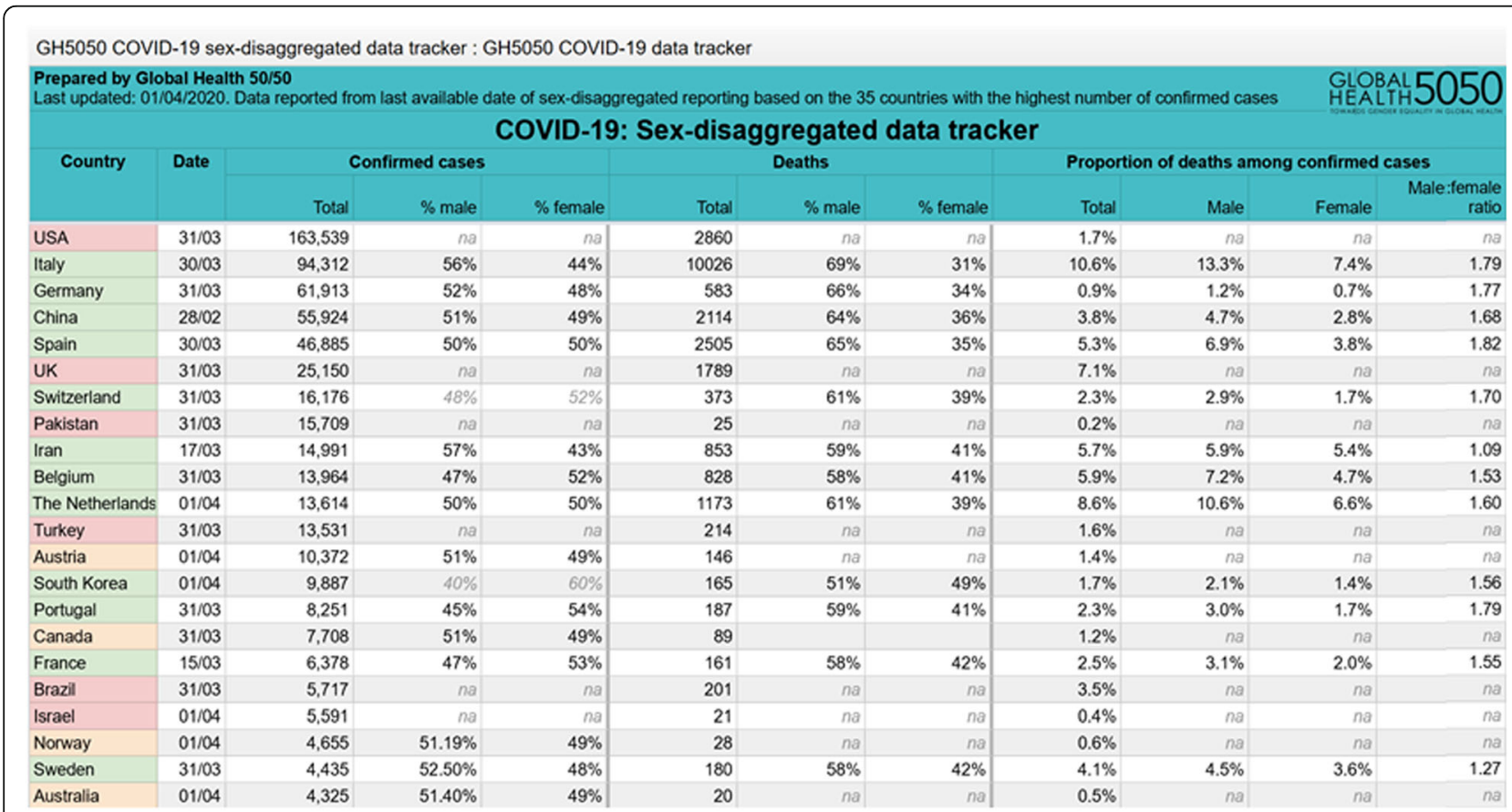

Fig. 1 Sex-disaggregated data of confirmed COVID-19 cases and deaths provided by Global Health 50\%50 data tracker as of April 2, 2020 [16] 


\section{Male:female ratios Covid-19}

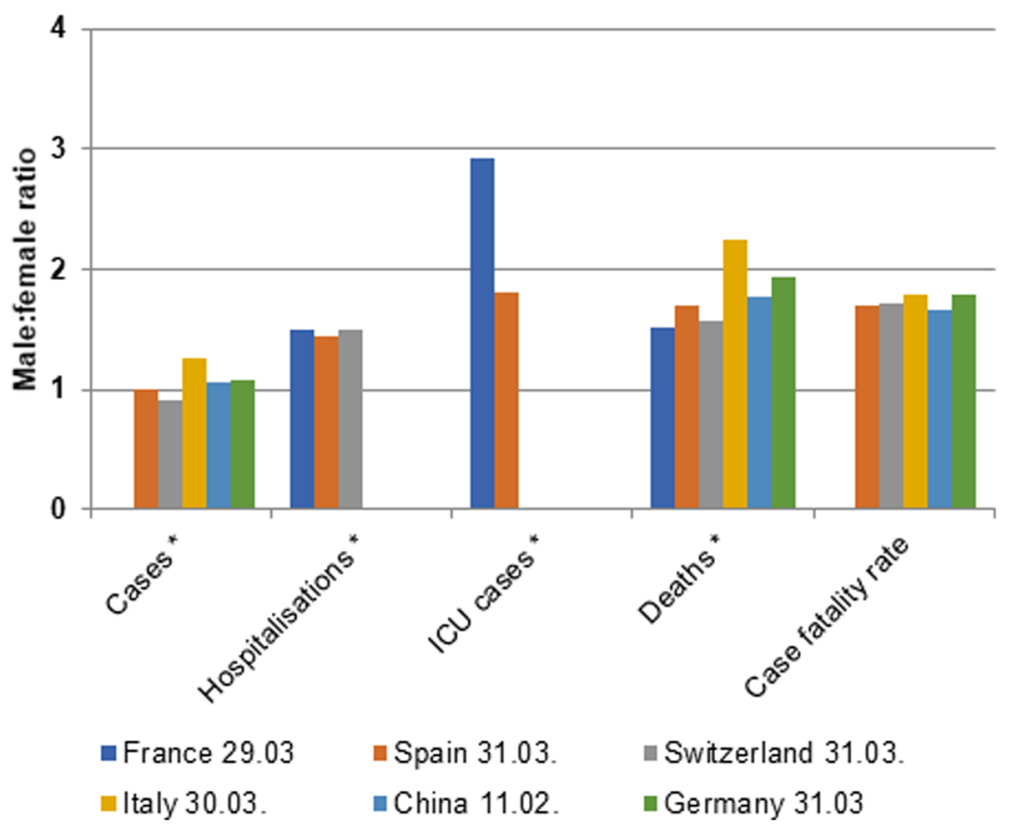

Fig. 2 Male to female ratios of COVID-19 cases, hospitalizations, intensive care unit (ICU) admissions, deaths, and case-fatality rates in European countries and China as of April 2, 2020. *absolute numbers are provided. Sex-disaggregated data were not available for all indicators

women by 74, 87, and 108 per 100,000 Swiss inhabitants, respectively. In Germany, relative differences between men and women were similar to Switzerland, but at a lower level, with the incidence in Germany being onethird of that in Switzerland. It is notable, however, that the number of confirmed cases and therefore also the incidence depends largely on testing strategy in countries and regions.

Novel data on disease course and severity show 50\% more hospitalized men than women (Fig. 2). Notably, although the overall number of confirmed COVID-19 cases across all age groups is currently sex balanced in Switzerland, the hospitalizations in men exceed the one observed in women by 1.5 -fold. A similar gender distribution in hospitalization rates is observed in France. This imbalance supports a higher susceptibility of men to develop severe respiratory disease following SARSCoV2 infection, leading to more hospital admissions. While the number of ICU admissions of men and women are currently unknown in Switzerland, in France, and in the Lombardy region (Italy), the number of men receiving ICU care is 3-fold and 4-fold higher than the number of women [23]. The latter might be indicative of gender differences in COVID-19 disease severity; however, gender inequity in ICU admission policies may also play a role.

Significant differences in the male to female COVID19 case fatality ratio can be observed between European countries. The latter may also reflect the age-sex mix of cases by country as well as national testing strategies, besides case fatality. Nevertheless, case fatality rates reported in China, Italy, Spain, France, Germany, and Switzerland are relatively homogenous and range between 1.7-1.8. This supports the view that a consistent biological phenomenon is operating, accounting for the higher case fatality in men, independent of countryspecific demographics and testing strategies (Fig. 2) [17$19,21,22]$. In addition, pooled data comprising 227,219 confirmed cases and 14,364 deaths suggest that the male to female case fatality ratio is consistently elevated through all age groups and may even be most pronounced at middle age (Fig. 3). The latter is a novel observation which further supports the notion that age as well as gender-specific behavior and/or biological variables interact in COVID-19 disease vulnerability. However, more data are needed to confirm an interaction between age and sex in COVID-19 case fatality.

\section{Sex differences in ACE2 and TMPRSS2 regulation}

To enter cells, SARS-Cov-2 binds to the angiotensin converting enzyme (ACE) 2 receptor and the cellular serine protease TMPRSS2 for priming [24] (Fig. 5). ACE2 is a membrane-bound protein and is expressed in multiple tissues including the cardiovascular system, adipose tissue, gut and kidneys, the central nervous system, and in the lungs [25]. The cell-associated form of ACE2 is required for SARS-CoV virus entry into target cells [26]. ACE2 is cleared from the cells by the 


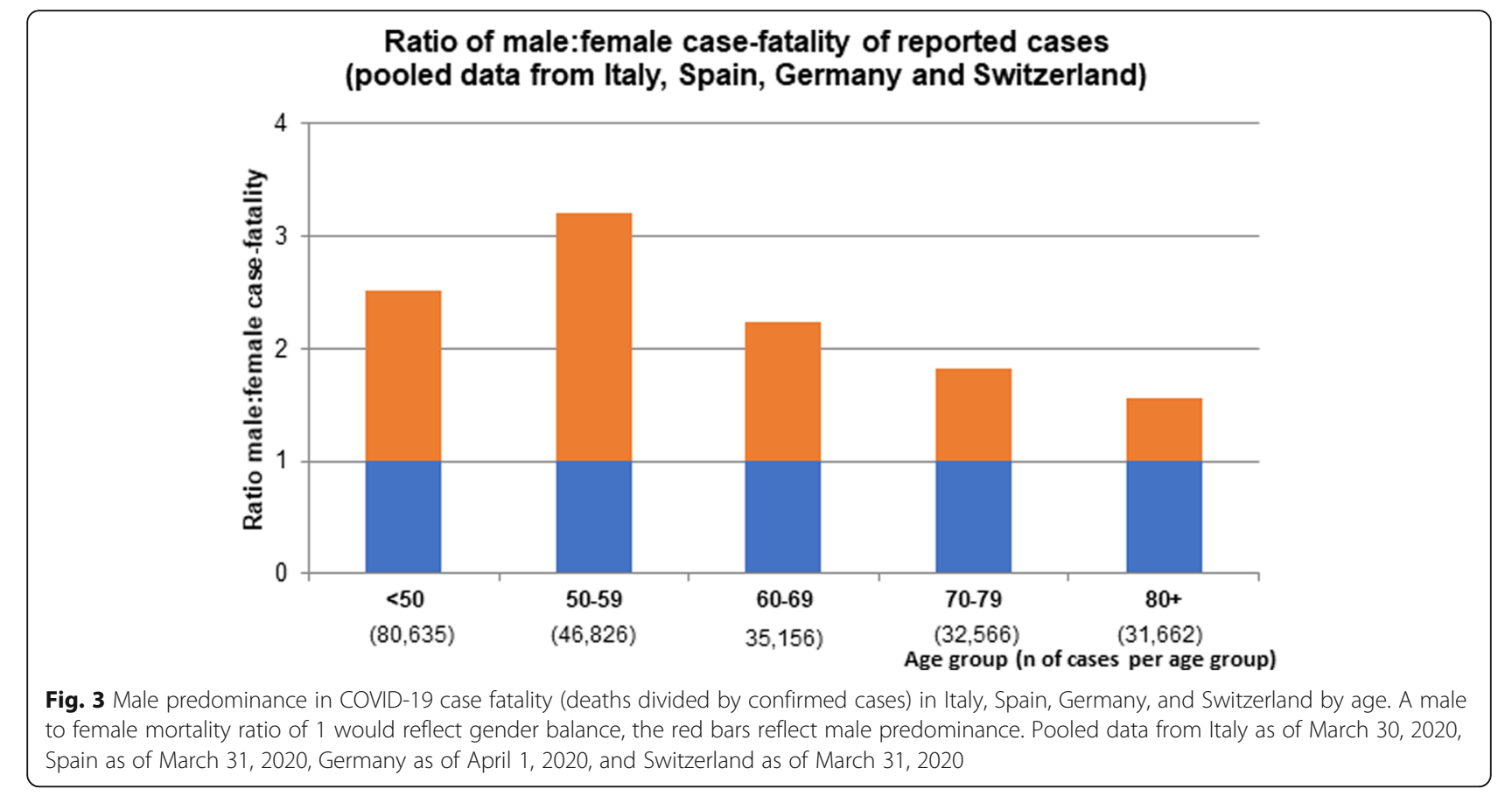

metalloproteases ADAM10 and ADAM17 [26, 27]. Some reports indicate that circulating levels of ACE2 are higher in healthy and diabetic men as well as in men with renal disease as compared to women [28]. Others found no sex difference but reported higher ACE2 serum activity in older compared to younger women [29]. In patients with type 1 diabetes, circulating ACE2 activity increases with increasing vascular tone and in the presence of microvascular or macrovascular atherosclerotic disease [30]. Soluble ACE2 is enzymatically active and has modest inhibitory effects on viral infection efficiency [31]. However, these data are not yet coherent and the link between circulating ACE2 and COVID-19 is not clear.

ACE2 plays a crucial role in the renin angiotensin aldosterone system (RAAS) as it opposes the vasoconstrictor actions of angiotensin II by converting angiotensin II to vasodilatory angiotensin 1-7 in different organs. ACE2 regulates the cellular biology of cardiomyocytes, cardiac fibroblasts, and coronary endothelial cells in both heart failure with reduced ejection fraction (HFrEF) and heart failure with preserved ejection fraction (HFpEF) models and after experimental myocardial infarction [32, 33]. Therefore, increasing ACE2 activity was considered a potential therapeutic option for COVID-19 [34]. However, a previous report suggests that high protein expression of ACE2 receptor in specific organs was associated with organ failure in patients infected by SARS in 2002/2003 [35], while 35\% of myocardial tissue samples of patients who died from SARS showed a reduced myocardial ACE2 protein expression along with viral RNA [36]. A loss of ACE2 function through endocytosis and activation of proteolytic cleavage following SARS-CoV-2 binding has recently been described and could reconcile these apparently contradictory findings [25].

In the lung, ACE2 is primarily expressed in bronchial transient secretory cells or type II alveolar cells [37]. Experimental evidence derived from murine and rat models suggests a protective role of ACE2 activators in vascular remodeling during pulmonary hypertension, in allergic airway inflammation associated with asthma, and in the reduction of pulmonary fibrosis [38, 39]. Further, ACE2 activation improved pulmonary endothelial function in a rat model of pulmonary hypertension via the endothelial nitric oxide synthase (eNOS) pathway and seems to play an important role in smoking-induced lung injury [40]. Indeed, the latter was associated with a significant reduction of ACE2 expression in lung tissue which was reversed by Losartan treatment [41]. These preclinical studies suggest a protective role and a potential therapeutic use of ACE2 in a variety of pulmonary diseases. It is however currently unclear whether the role of ACE2 in pulmonary pathologies differs by sex. In addition to the above mentioned studies, ACE inhibitors and angiotensin receptor blockers (ARBs) have been reported to upregulate ACE2 expression in different organs in humans [42, 43] and experimental animals [44], whereas no effect of ACE inhibitors or ARBs on ACE2 activity was found in other reports [33]. The interaction between COVID-19 and ACE inhibitors or ARBs in patients with heart disease was recently reviewed [45]. This 
topic is out of the scope of the present review which focuses on sex differences.

There is increasing evidence that sex and sex hormones affect many components of the circulating as well as tissue-based RAAS including ACE2 [46-50] (Fig. 4). Downregulation of angiotensin II receptor type 1 (AT1R) by estrogens, and regulation of renin activity by estrogens have been described and reviewed elsewhere $[51,52]$. More recently, it was shown that estrogen modulates the local RAAS in human atrial myocardium via downregulation of ACE and simultaneous upregulation of ACE2, AT2R, and MAS expression levels [53]. The ACE2/Ang1-7/Mas receptor axis appears to be of greater relevance in women than in men [47]. Indeed, genes coding for ACE2 and angiotensin II receptor 2 (AT2R) are located on the $\mathrm{X}$ chromosome suggesting a potential for higher expression in women [54]. Nevertheless, reports from a number of preclinical studies agree that ACE2 is frequently higher expressed in males than in females, mainly under pathological conditions $[47,50,55]$.

In addition to sex chromosome complement, sex hormones promote opposite effects on ACE and ACE2 activity, cardiac hypertrophy, and contractility in spontaneously hypertensive rats [56]. Ovariectomy led to increased ACE2 activity in females, whereas in males, orchiectomy decreased ACE2 activity. In agreement with these data, ovariectomy increased ACE2 expression in the female kidney, and adipose tissue, and estradiol replacement reduced ACE2 expression [46]. Thus, testosterone seems to maintain high ACE2 levels in the heart and kidney, whereas estrogen reduces ACE2 expression in these organs. Based on these data, we must assume that a significant interaction between sex hormones and ACE2 expression exists.

In humans, several clinical trials highlight the relevance of sex differences in the RAAS. In fact, a recent prospective cohort study indicates that women require lower doses of ACE inhibitors for heart failure treatment than men [57]. Also, the neprilysin (NEP) inhibitor sacubitril, which degrades angiotensin peptides, in combination with valsartan, has recently been shown to exert beneficial effects in women with HFpEF, but less so in men [58]. Unfortunately, specific mechanisms accounting for this difference have not been reported in these studies. A higher tissue expression of ACE2 has been observed in Asian men as compared to women [28, 59], while in our own unpublished investigation in tissue samples from patients with aortic valve stenosis, ACE2 was upregulated 4-5 fold in the myocardium of men as compared to their female counterparts. In contrast, no

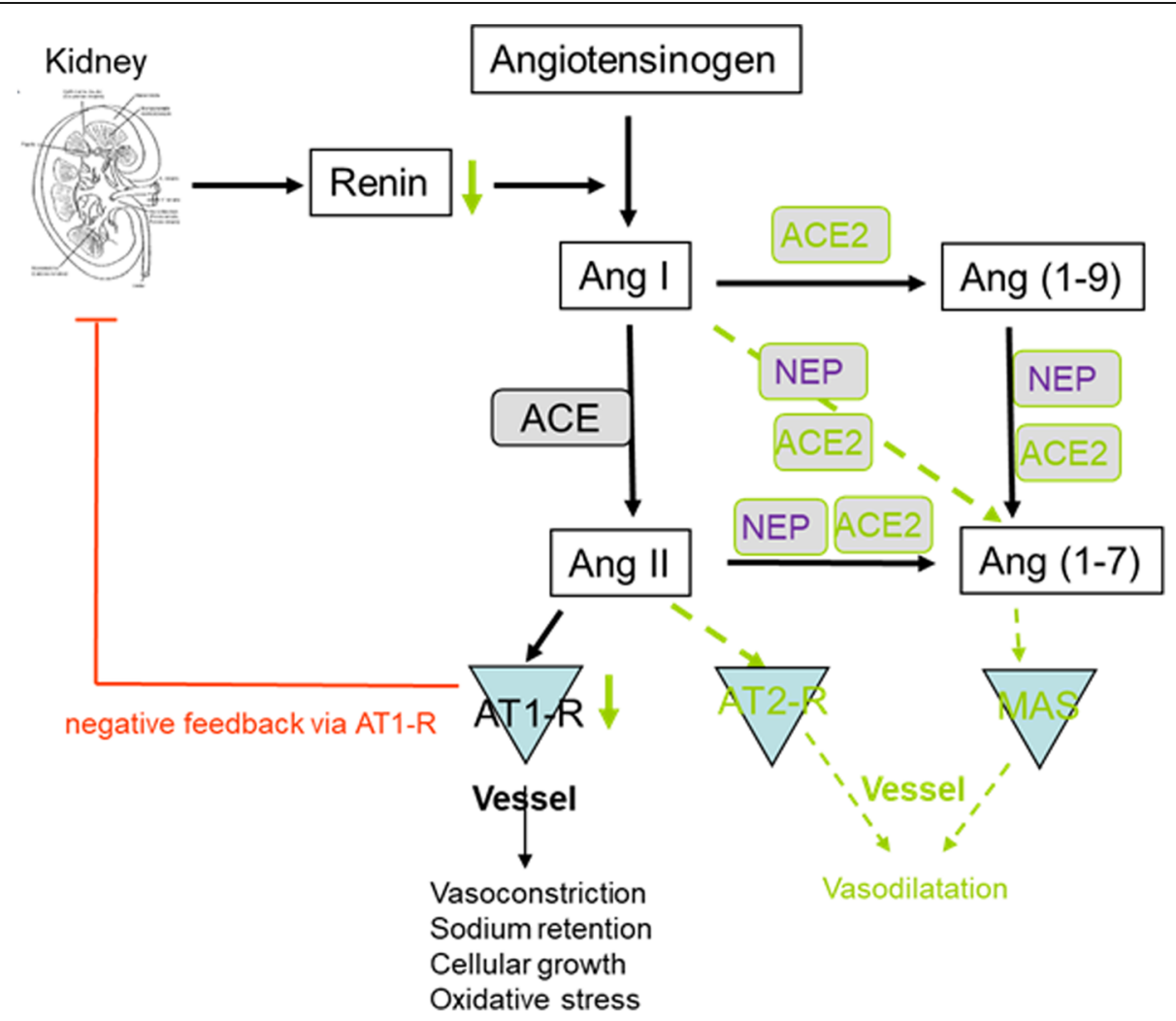

Fig. 4 Estrogen and sex regulate components of the renin angiotensin aldosterone system (RAAS). Estrogen-regulated pathways are depicted in green. AT2R angiotensin II type 2 receptor, ACE2 angiotensin converting enzyme 2, NEP neutral endopeptidase neprilysin 
sex difference in ACE2 expression was seen in control hearts [60]. Whether these sex differences in ACE2 regulation are of clinical relevance remains to be determined.

The second protein, necessary for SARS-CoV2 invasion into cells, the cell-surface serine protease TMPRSS2 is predominantly expressed in prostate epithelium, in high-grade prostate cancers, and in the majority of human prostate cancer metastases [61, 62]. Although TMPRSS2 is expressed several fold higher in the prostate relative to any other human tissue, the serine protease has also been detected in airway epithelia where its normal physiologic function remains unknown [63]. TMPRSS2 transcription is regulated by androgenic ligands and an androgen receptor binding element in the promoter [64] (Fig. 5). Notably, recurrent gene fusions of the $5^{\prime}$ untranslated region of TMPRSS2 to the transcription factor ERG is the most frequent genomic alteration in early- and late-stage prostate cancer and results in overexpression of ERG. The latter is present in both early- and late-stage prostate cancer [64]. However, it is currently unclear under which conditions the fusion protein is generated, whether TMPRSS2 is also regulated by estrogen, and whether it plays a role in COVID-19. The involvement of TMPRSS2 in viral $S$ protein priming might explain, at least in part, the higher case fatality seen in males affected by COVID-19. Accordingly, a TMPRSS2 inhibitor has recently been shown to block entry of the virus in vitro and might become a therapeutic strategy for antiviral intervention [24]. Whether previous prostate cancer and anti-androgenic treatment might affect virus entry and the course of disease is currently unknown [64].

\section{Sex differences in immune responses to viruses}

Females and males differ in their susceptibility and response to viral infections, leading to sex differences in incidence and disease severity [65]. For infectious diseases caused by viruses, there are numerous and diverse ways in which sex and gender can impact differential susceptibility between males and females. For example,

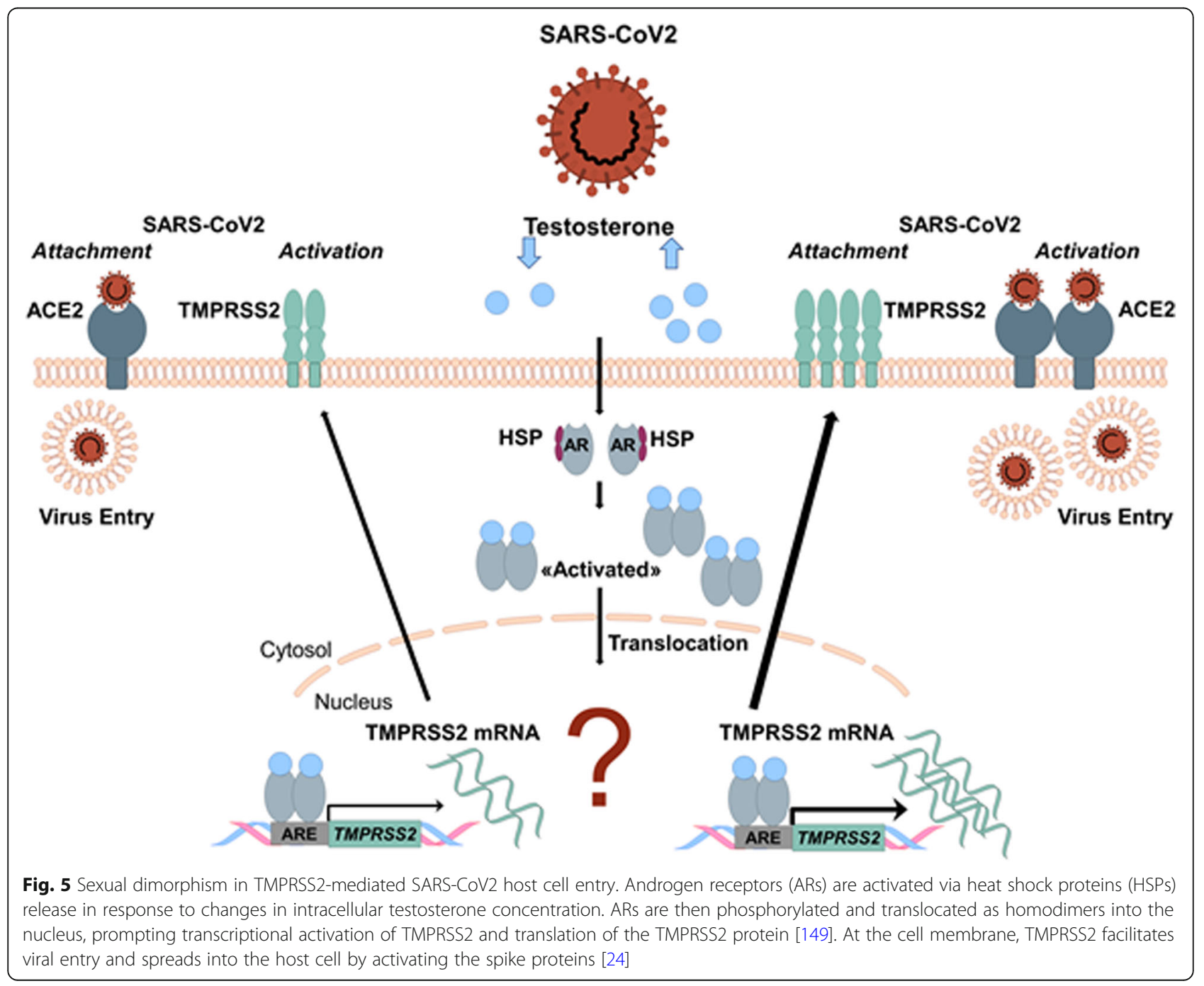


human studies reveal that females have over $40 \%$ less human immunodeficiency virus (HIV) RNA in circulation than males. Despite having less circulating HIV RNA than males, females who are matched with males on their HIV RNA loads have a 1.6-fold higher risk of developing AIDS [66]. Although exposure to influenza A viruses is often higher in males, fatality following exposure to pathogenic influenza A viruses is reportedly higher in females [67]. In contrast, the prevalence of serum hepatitis B virus (HBV) surface antigen, HBV DNA titers, and development of hepatocellular carcinoma is higher in males than females [68-70].

The innate recognition and response to viruses as well as downstream adaptive immune responses during viral infections differ between females and males. The number and activity of innate immune cells, including monocytes, macrophages, and dendritic cells (DCs) as well as inflammatory immune responses in general are higher in females than in males [71-73]. Toll-like receptor (TLR) 7 is a pattern recognition receptor in the endosomes of several immune cells, including plasmacytoid DCs and B cells, and is used to detect single stranded RNA viruses, including coronaviruses. The TLR7 gene, encoded on the $\mathrm{X}$ chromosome, may escape $\mathrm{X}$ inactivation resulting in higher expression levels of TLR7 in females when compared to males [74-76]. Exposure of peripheral blood mononuclear cells (PBMCs) to TLR7 ligands in vitro causes higher production of interferon- $\alpha$ (IFN $\alpha$ ) in cells from females than from males [77], and plasmacytoid DCs (pDCs) from females and female mice have higher basal levels of IFN regulatory factor 5 (IRF5) and IFN $\alpha$ production following TLR7 ligand stimulation [78]. Immune responses to viruses can vary with changes in sex hormone concentrations naturally observed over the menstrual cycle, following contraception, after menopause and during hormone replacement therapy (HRT) as well as during pregnancy [79].

With regard to adaptive immune responses, females generally exhibit greater humoral and cell-mediated immune responses to antigenic stimulation, vaccination, and infection than do males [80]. Both basal levels of immunoglobulin [81] as well as antibody responses are consistently higher in females than in males [82]. In humans, global analysis of B cell gene expression signatures reveals that the majority of genes differentially expressed between the sexes are significantly upregulated in B cells from adult females compared with males [83]. Clinical studies reveal that males have lower CD3+ and $\mathrm{CD} 4+$ cell counts, CD4+:CD8+ cell ratios, and helper $\mathrm{T}$ cell type 1 (Th1) responses than females [8487]. Females also exhibit higher cytotoxic $\mathrm{T}$ cell activity along with upregulated expression of antiviral and proinflammatory genes, many of which have estrogen response elements in their promoters [88].
Sex steroids, particularly testosterone (T), estradiol (E2), and progesterone (P4), influence the functioning of immune cells. Sex steroids alter the functioning of immune cells by binding to specific receptors, which are expressed in various lymphoid tissue cells as well as in circulating lymphocytes, macrophages, and dendritic cells [89]. The binding of sex steroids to their respective steroid receptors directly influences cell signaling pathways, including NF-kB, cJun, and interferon regulatory factor (IRF) 1, resulting in differential production of cytokines and chemokines [89]. Although direct effects of gonadal steroids cause many sex differences in immune function, some sex differences might be caused by the inherent imbalance in the expression of genes encoded on the $\mathrm{X}$ and $\mathrm{Y}$ chromosomes [90]. Polymorphisms or variability in sex chromosomal genes as well as in autosomal genes that encode for immunological proteins can also contribute to sex differences in immune responses [91].

Sex differences in immune response in cardiac tissues also depend on age. We have recently shown that females develop stronger chronic immune reactions in the myocardium with old age [92]. Aging is associated with the development of a chronic low-grade inflammatory phenotype (CLIP) [93]. Such CLIP may be induced by chronic viral infections, among others. Cellular senescence may also contribute to CLIP as senescent cells circulate in the tissues through the body. They secrete a variety of pro-inflammatory mediators, stimulating CLIP. Furthermore, factors as smoking, decreased production of sex steroids, and accumulation of adipose tissue may also contribute to CLIP.

\section{Gender-related risk factors and impact}

When considering differentials in incidence and case fatality between males and females, we must also consider how sex intersects with gender to influence vulnerability. Gender is defined as the social and cultural norms, roles, attributes, and behaviors that a society considers appropriate for men and women or boys and girls [94]. Evidence suggests that the current COVID-19 pandemic has both primary and secondary effects related to sex and gender. Primary effects include differences between males/men and females/women in incidence and case fatality, while secondary effects include differences in social and economic consequences as a result of the pandemic, including risk of domestic violence $[95,96]$, economic and job insecurity, and increased domestic workload [15].

Preliminary data indicate an association between comorbidities, such as chronic lung disease, hypertension, and cardiovascular disease, and severity of COVID-19 [16]. Worldwide, these morbidities are higher among men than women [97], except for older age groups. Gender differences in risk behaviors, such as smoking and 
drinking, may be contributing to the gender gaps in mortality of such non-communicable diseases [13]. Smoking and drinking rates are higher among men than women worldwide. Such behaviors are associated with the risk of developing comorbidities [16]. These behaviors are linked to gender norms related to what is considered appropriate behaviors and activities for men and women [98]. Other gendered norms and behaviors which may be contributing to a higher incidence among men include lower rates of hand washing, which is a recognized preventative measure, and delayed healthcare seeking [16]. Evidence from China suggests that patients whose diagnoses were delayed were at greater risk of dying [99]. In this regard, greater system delays between onset of symptoms and initiation of treatment have been described in women with cardiovascular disease [100]; however, no data on prehospital delays in COVID-19 are currently available. Thus, it is currently unknown whether potential gender differences in prehospital delays impose disadvantages on women. Other gendered differences which place women and men at differential risk of infection and/or mortality include rejection of social isolation, social obligations, psychological stress, low quality of life, and low socioeconomic status among COVID-19 [13]. A careful analysis of a patient's history including traditional cardiovascular risk factors, socioeconomic status, menopausal status, age at menopause, number of pregnancies, pregnancy-related complications, fertility treatments, postmenopausal HRT, hormonal contraception, history of breast or prostate cancer, and aromatase inhibitors/anti-androgenic treatments will be essential to discover mechanisms accounting for the gender disparities in COVID-19.
Women's roles as caregivers-both within the health system and at home-may place them at increased risk of infection. Approximately $70 \%$ of health and social care workforce worldwide are women [101], including frontline healthcare workers. Women are also more likely to care for children or other relatives who are ill [15]. Overall, more research is needed to understand how sex and gender, and the intersection of sex and gender, is causing differential outcomes and effects related to COVID-19 among and between men and women. In particular, there is a need to evaluate the influence of such gender variables on disease manifestation and outcomes.

\section{Sex differences in COVID-19 treatment approaches}

Vaccines are the best prophylactic treatment for infectious diseases as they provide immunity and protection prior to infection. Sex and gender impact vaccine acceptance, responses, and outcomes. Females are often less likely to accept vaccines, but once vaccinated, develop higher antibody responses (i.e., primary correlate of protection) and report more adverse reactions to vaccines than males (Table 1) [80]. For example, after vaccination against influenza, yellow fever, rubella, measles, mumps, hepatitis $\mathrm{A}$ and $\mathrm{B}$, herpes simplex 2, rabies, smallpox, and dengue viruses, protective antibody responses are twice as high in adult females as compared with males [80]. Data from inactivated influenza vaccines indicate that adult (18-45 years of age) females develop greater IL- 6 and antibody responses than males, with diminished differences between the sexes among aged individuals (65+ years of age) [128]. Reduced male-female differences in immune responses to the monovalent

Table 1 Sex differences in adverse reactions, immune responses, and efficacy of vaccines and antiviral drugs in humans

\begin{tabular}{|c|c|c|c|c|}
\hline Virus & Antiviral drug/vaccine & $\begin{array}{l}\text { Sex-specific } \\
\text { features }\end{array}$ & Comments & References \\
\hline \multirow[t]{2}{*}{ HIV } & HAART & $M<F$ & $\begin{array}{l}\text { CD4+ T cell count, adverse reactions, fat accumulation, drug } \\
\text { concentration, virus clearance, hepatitis }\end{array}$ & [102-108] \\
\hline & HAART & $M>F$ & Fat loss, survival & {$[103,109]$} \\
\hline \multirow[t]{3}{*}{ HSV-2 } & HSV-2 gD vaccine & $M<F$ & $\begin{array}{l}\text { Humoral immune responses, cell-mediated immune responses, vaccine } \\
\text { efficacy }\end{array}$ & [110-112] \\
\hline & Acyclovir & $M<F$ & Frequency of prescription, adverse reaction & {$[113,114]$} \\
\hline & Acyclovir & $M>F$ & Reduction of virus shedding & [114] \\
\hline HBV & HBV vaccine & $M<F$ & Humoral immune responses & [115-118] \\
\hline $\mathrm{HCV}$ & $\begin{array}{l}\text { Pegylated interferon } \\
\text { alpha/ribavirin }\end{array}$ & $M<F$ & Adverse reaction, sustained virologic response ${ }^{1}$ & [119-121] \\
\hline \multirow{4}{*}{$\begin{array}{l}\text { Seasonal influenza } \\
\text { viruses }\end{array}$} & TIV vaccine & $M<F$ & Humoral immune responses, adverse reactions & [122-125] \\
\hline & Oseltamivir & $M<F$ & Drug clearance and metabolism ${ }^{2}$ & {$[126]$} \\
\hline & Oseltamivir & $M>F$ & Alleviation of symptoms, reduction of viral load & [127] \\
\hline & Zanamivir & $M=F$ & Alleviation of symptoms, reduction of viral load & [127] \\
\hline
\end{tabular}

HAART highly active antiretroviral therapy, HBV hepatitis B virus, $H C V$ hepatitis $\mathrm{C}$ virus, HIV human immunodeficiency virus, HSV herpes simplex virus, TIV trivalent inactivated influenza virus. ${ }^{1}$ premenopausal females only, ${ }^{2}$ tested in neonates only 
2009 H1N1 vaccine among aged individuals is partly due to reproductive senescence in females, in which higher circulating estradiol concentrations in females are associated with greater antibody responses to the vaccine [128].

For treatment of COVID-19, a number of investigational agents are currently being explored including remdesivir, lopinavir-ritonavir, a combined protease inhibitor, chloroquine/hydroxychloroquine, colchicine, and tocilizumab, an IL-6 inhibitor [5]. Although some of these compounds have shown promise in inhibiting the growth of SARS-CoV2 in vitro [5, 129-131, 132], their "off-label" use carries the risk of adverse side effects such as cardiac arrhythmias and sudden cardiac death [133, 134]. In particular chloroquine and hydroxychloroquine, both antimalarial agents inhibiting the cell entry of SARS-CoV2 by under-glycosylation of ACE2 receptors $[129,130]$, are known to trigger life-threatening polymorphic ventricular tachycardia (torsades de pointes) by prolonging the heart rate-corrected QT (QTc) interval $[134,135]$. Previous reports indicate that women are more prone to develop drug-induced torsades de pointes than men, with $65-75 \%$ of drug-induced torsades de pointes occurring in women [136]. Indeed, there are substantial sex differences in the electrocardiographic pattern of ventricular repolarization with a longer QTc interval at baseline being observed in women [48, 136, 137]. Protective effects of testosterone have been suggested to account for the shorter QTc interval and the reduced incidence of drug-induced torsades de pointes in men. However, mechanisms underlying these differences are not fully understood. In addition, experimental and clinical studies have shown that chloroquine exerts different effects on adrenocortical function in female and male rats [138] and depresses testosterone secretion and sperm count in men [139]. The latter is of particular interest in the treatment of COVID-19 as the expression of TMPRSS2, a protein that primes SARS-CoV-2 entry into cells, is upregulated by androgens [140]. The latter has been suggested to account for the higher mortality seen in men affected by COVID-19. However, whether anti-androgenic treatment might affect virus entry and the course of disease is currently unknown.

Further, there is evidence that women encounter more often adverse drug reactions to antiviral treatment than men (Table 1). In addition, pharmacokinetics and treatment responses to antiretroviral therapy with ritonavir and lopinavir differ between males and females [141]. In fact, higher plasma concentrations of ritonavir and a higher total cholesterol:high-density lipoprotein (HDL) ratio have been reported in girls [141, 142], while an atazanavir plus ritonavir regimen was associated with a higher risk of virologic failure in women as compared to men [131].
The current off-label use of anti-inflammatory drugs, such as colchicine, for the reduction of excessive inflammation caused by SARS-CoV2 is also notable. The COLCORONA trial has just started recruiting patients with COVID-19 and will determine whether short-term treatment with colchicine reduces the rate of death and lung complications related to COVID-19 (https://clinicaltrials.gov/ct2/show/NCT04322682). The drug has recently regained popularity when it was shown that colchicine reduced the risk of ischemic cardiovascular events in patients with a recent myocardial infarction [143]. However, while the primary efficacy composite endpoint was reduced by colchicine in the total cohort and in men, a subgroup analysis pointed to a lower efficacy in women [143]. Also, previous experimental work in rats reports a higher acute oral toxicity of colchicine in females as compared to males with female rats being two times more susceptible to the lethal effects of colchicine than male rats [144]. Thus, a sex-specific analysis in the COLCORONA trial will be essential in order to take these differences into account.

Taken together, these data emphasize the importance to consider the effect of age, reproductive status, and exogenous hormonal manipulation when antiviral and other treatment strategies are applied to COVID-19 patients.

\section{Conclusion}

The sex and gender disparities observed in COVID-19 vulnerability emphasize the need to understand the impact of sex and gender on incidence and case fatality of the disease and to tailor treatment according to sex and gender. Experiences from past outbreaks and pandemics have clearly shown the importance of incorporating a sex and gender analysis into preparedness and response efforts of health interventions [67, 145-148]. Policies and public health efforts, however, have not yet addressed the gendered impacts of disease epidemics, outbreaks, or pandemics. Some countries have not disaggregated data by sex and age the way other countries have. In conclusion, governments in all countries should disaggregate and analyze data for sex and age differences. Furthermore, as prophylactic and therapeutic treatment studies begin, inclusion of sex and gender analyses in their protocols must occur.

\footnotetext{
Abbreviations

ARs: Androgen receptors; ARDS: Acute respiratory distress syndrome; ACE: Angiotensin converting enzyme 2; ARBs: Angiotensin receptor blockers; AT2R: Angiotensin II receptor; CLIP: Chronic low-grade inflammatory phenotype; COVID-19: Coronavirus disease 2019; DCs: Dendritic cells; HAART: Highly active antiretroviral therapy; HFpEF: Heart failure with preserved ejection fraction; QTc: Heart rate-corrected QT interval; HSPs: Heat shock proteins; Th1: Helper T cell type 1; HBV: Hepatitis B virus; HCV: Hepatitis C virus; HSV: Herpes simplex virus; HDL: High density lipoprotein; HIV: Human immunodeficiency virus; ICU: Intensive care unit; NEP: Neutral endopeptidase; HRT: Postmenopausal hormone replacement therapy; SARS-CoV2: Severe
} 
acute respiratory syndrome coronavirus 2; TIV: Trivalent inactivated influenza virus; TLR: Toll-like receptor; RAAS: Renin angiotensin aldosterone system; WHO: World Health Organization

\section{Acknowledgements}

We thank Dr. Susan Bengs and Dr. Ahmed Haider for their help in preparing the figures of this manuscript and Ms Anna Metterhausen for helping with the literature search. We thank Ms Michaela Diercke for providing epidemiological data from Germany. We thank Prof. Beatrice Beck Schimmer for her continued support of gender-specific medicine at the University of Zurich.

\section{Authors' contributions}

HKN analyzed and interpreted the patient data regarding COVID-19 case fatality and mortality, CG and VRZ were major contributors in designing and writing the manuscript, SLK wrote the paragraphs on sex differences in antiviral treatment and immune responses, and RM wrote the paragraph on gender-related risk factors and impact. All authors read and approved the final manuscript.

\section{Funding}

CG was supported by grants from the Swiss National Science Foundation (SNSF), the Olga Mayenfisch Foundation, Switzerland, the OPO Foundation, Switzerland, the Novartis Foundation, Switzerland, the Swissheart Foundation, the Helmut Horten Foundation, Switzerland, the EMDO Foundation, Switzerland, the Iten-Kohaut Foundation, Switzerland, and the University Hospital Zurich Foundation. SK and RM were suppored by the $\mathrm{NIH/ORWH/NIA} \mathrm{Specialized} \mathrm{Center} \mathrm{of} \mathrm{Research} \mathrm{Excellence} \mathrm{in} \mathrm{Sex} \mathrm{Differences}$ (U54AG062333). VRZ is funded by EU (Gender Academy 824585), BMG (GeSeMS, ZMVL1-2520FSB431) and BMBF (DZHK-Gender 81Z2100201; Gendage 01GL1716B).

\section{Availability of data and materials}

Not applicable

\section{Ethics approval and consent to participate}

Not applicable

\section{Consent for publication}

Not applicable

\section{Competing interests}

None declared

\section{Author details}

${ }^{1}$ Department of Nuclear Medicine, University Hospital Zurich, Raemistrasse 100, 8091 Zurich, Switzerland. ${ }^{2}$ Center for Molecular Cardiology, University of Zurich, Schlieren, Switzerland. ${ }^{3}$ Department of Internal Medicine II, Medical University of Vienna, Vienna, Austria. ${ }^{4}$ University of Zurich, Zurich, Switzerland. ${ }^{5}$ Charité, Universitätsmedizin Berlin, Berlin, Germany. ${ }^{6} \mathrm{DZHK}$ (German Centre for Cardiovascular Research), partner site Berlin, Berlin, Germany. ${ }^{7}$ Robert Koch Institute, Berlin, Germany. ${ }^{8}$ Department of International Health, The Johns Hopkins Bloomberg School of Public Health Baltimore, Maryland, USA. ${ }^{9}$ W. Harry Feinstone Department of Molecular Microbiology and Immunology, The Johns Hopkins Bloomberg School of Public Health, Baltimore, Maryland, USA.

Received: 6 April 2020 Accepted: 24 April 2020

Published online: 25 May 2020

\section{References}

1. Guan WJ, Ni ZY, Hu Y, Liang WH, Ou CQ, He JX, et al. Clinical characteristics of coronavirus disease 2019 in China. N Engl J Med. 2020. https://doi.org/10. 1056/NEJMoa2002032

2. Who director-general's opening remarks at the media briefing on Covid-19 - 11 March 2020. 2020. World Health Organisation. https://www.who.int/dg/ speeches/detail/who-director-general-s-opening-remarks-at-the-mediabriefing-on-covid-19\%2D\%2D-11-march-2020 (Date accessed:22.03.2020).

3. Coronarvirus Resource Center, Johns Hopkins University Medicine. 2020. Johns Hopkins University Medicine. Medicine JHU. https://coronavirus.jhu. edu/map.html (Date accessed:22.03.2020).
4. Dong E, Du H, Gardner L. An interactive web-based dashboard to track Covid-19 in Real Time. Lancet Infect Dis. 2020. https://doi.org/10.1016/ s1473-3099(20)30120-1.

5. Roche to start phase III trial of actemra in Covid-19 patients. 2020. https:// www.clinicaltrialsarena.com/news/roche-actemra-covid-19-trial/ (Date accessed:22.03.2020).

6. Wu C, Chen X, Cai Y, Xia J, Zhou X, Xu S, et al. Risk factors associated with acute respiratory distress syndrome and death in patients with coronavirus disease 2019 pneumonia in Wuhan, China. JAMA Intern Med. 2020. https:// doi.org/10.1001/jamainternmed.2020.0994.

7. Wang D, Hu B, Hu C, Zhu F, Liu X, Zhang J, et al. Clinical characteristics of 138 hospitalized patients with 2019 novel coronavirus-infected pneumonia in Wuhan, China. Jama. 2020. https://doi.org/10.1001/jama.2020.1585.

8. Grasselli G, Pesenti A, Cecconi M. Critical Care Utilization for the COVID-19 Outbreak in Lombardy, Italy: Early Experience and Forecast During an Emergency Response. Jama 2020. https://doi.org/10.1001/jama.2020.4031.

9. Onder G, Rezza G, Brusaferro S. Case-fatality rate and characteristics of patients dying in relation to Covid-19 in Italy. JAMA. 2020. https://doi.org/ 10.1001/jama.2020.4683

10. Zhao S, Cao P, Chong MK, Gao D, Lou Y, Ran J, et al. The time-varying serial interval of the coronavirus disease (Covid-19) and its gender-specific difference: a data-driven analysis using public surveillance data in Hong Kong and Shenzhen, China from January 10 to February 15, 2020. Infect Control Hosp Epidemiol. 2020. https://doi.org/10.1017/ice.2020.64:1-8.

11. Mo P, Xing Y, Xiao Y, Deng L, Zhao Q, Wang H, et al. Clinical characteristics of refractory Covid-19 pneumonia in Wuhan, China. Clin Infect Dis. 2020, https://doi.org/10.1093/cid/ciaa270.

12. Conti P, Younes A. Coronavirus Cov-19/Sars-Cov-2 affects women less than men: clinical response to viral infection. J Biol Regul Homeost Agents. 2020;34(2).

13. Cai H. Sex difference and smoking predisposition in patients with Covid-19. Lancet Respir Med. 2020. https://doi.org/10.1016/s2213-2600(20)30117-x.

14. Bhopal R. Covid-19 Worldwide: We need precise data by age group and sex urgently. Bmj. 2020;369:m1366.

15. Wenham C, Smith J, Morgan R. Covid-19: the gendered impacts of the outbreak. Lancet. 2020;395(10227):846-8.

16. Sex, gender and Covid-19. 2020. Global Health 5050. https:/globalhealth505 0.org/covid19/ (Date accessed:02.04.2020).

17. Epidemia Covid-19, Aggiornamento Nazionale. 2020. Dipartimento Malattie Infettive e Servizio di Informatica, Istituto Superiore di Sanità. https://www. epicentro.iss.it/coronavirus/bollettino/Bollettino-sorveglianza-integrataCOVID-19_30-marzo-2020.pdf (Date accessed:30.03.2020).

18. The epidemiological characteristics of an outbreak of 2019 novel coronavirus diseases (Covid-19) - China, 2020. 2020. The Novel Coronavirus Pneumonia Emergency Response Epidemiology Team, China CDC Weekly. http://www.ne. jp/asahi/kishimoto/clinic/cash/COVID-19.pdf (Date accessed:03.04.2020).

19. Actualización Nº62. Enfermedad Por El coronavirus (Covid-19). 2020. Centro de Coordinación de Alertas y Emergencias Sanitarias, Secretaria General de Sanidad. https://www.mscbs.gob.es/profesionales/saludPublica/ccayes/alertasActual/nCovChina/documentos/Actualizacion_62_COVID-19.pdf (Date accessed:03.04.2020).

20. Chene G. Nouveaux Indicateurs Covid-19 Quotidiens. 2020. France Sp. https:// geodes.santepubliquefrance.fr/\#c = home (Date accessed:03.04.2020).

21. Coronavirus disease 2019 (Covid-19) daily situation report of the Robert Koch Institute 2020. Robert Koch Institute. Institute RK. https:/www.rki.de/ DE/Content/InfAZ/N/Neuartiges_Coronavirus/Situationsberichte/2020-04-01en.pdf? blob = publicationFile (Date accessed:03.04.2020).

22. New coronavirus: current situation - Switzerland and international. 2020. Federal Office of Public Health FOPH. FOPH FOoPH. https://www.bag.admin. ch/bag/fr/home/krankheiten/ausbrueche-epidemien-pandemien/aktuelleausbrueche-epidemien/novel-cov/situation-schweiz-und-international.html (Date accessed:03.04.2020).

23. Grasselli G, Zangrillo A, Zanella A, Antonelli M, Cabrini L, Castelli A, et al. Baseline characteristics and outcomes of 1591 patients infected with SarsCov-2 admitted to Icus of the Lombardy Region, Italy. Jama. 2020. https:// doi.org/10.1001/jama.2020.5394.

24. Hoffmann M, Kleine-Weber H, Schroeder S, Kruger N, Herrler T, Erichsen S, et al. Sars-Cov-2 cell entry depends on Ace2 and Tmprss2 and is blocked by a clinically proven protease inhibitor. Cell. 2020. https://doi.org/10.1016/j.cell.2020.02.052.

25. Gheblawi M, Wang K, Viveiros A, Nguyen Q, Zhong JC, Turner AJ, et al. Angiotensin converting enzyme 2: Sars-Cov-2 receptor and regulator of the renin-angiotensin system. Circ Res. 2020. https://doi.org/10.1161/circresaha. 120.317015 . 
26. Jia HP, Look DC, Tan P, Shi L, Hickey M, Gakhar L, et al. Ectodomain shedding of angiotensin converting enzyme 2 in human airway epithelia. Am J Physiol Lung Cell Mol Physiol. 2009;297(1):L84-96.

27. Jia HP, Look DC, Shi L, Hickey M, Pewe L, Netland J, et al. Ace2 receptor expression and severe acute respiratory syndrome coronavirus infection depend on differentiation of human airway epithelia. J Virol. 2005;79(23): 14614-21.

28. Patel SK, Velkoska E, Burrell LM. Emerging Markers in Cardiovascular Disease: Where Does Angiotensin-Converting Enzyme 2 Fit In? Clin Exp Pharmacol Physiol. 2013;40(8):551-559.

29. Fernandez-Atucha A, Izagirre A, Fraile-Bermudez AB, Kortajarena M, Larrinaga $G$, Martinez-Lage $P$, et al. Sex differences in the aging pattern of renin-angiotensin system serum peptidases. Biol Sex Differ. 2017;8:5.

30. Soro-Paavonen A, Gordin D, Forsblom C, Rosengard-Barlund M, Waden J, Thorn L, et al. Circulating Ace2 activity is increased in patients with type 1 diabetes and vascular complications. J Hypertens. 2012;30(2):375-83.

31. Jia HP, Look DC, Tan P, Shi L, Hickey M, Gakhar L, et al. Ectodomain shedding of angiotensin converting enzyme 2 in human airway epithelia. American journal of physiology. Lung cellular and molecular physiology. 2009;297(1):L84-96.

32. Patel VB, Zhong JC, Grant MB, Oudit GY. Role of the Ace2/angiotensin 1-7 axis of the renin-angiotensin system in heart failure. Circ Res. 2016;118(8):1313-26.

33. Burchill L, Velkoska E, Dean RG, Griggs K, Patel SK, Burrell LM. Combination renin-angiotensin system blockade and angiotensin-converting enzyme 2 in experimental myocardial infarction: implications for future therapeutic directions. Clin Sci (Lond). 2012;123(11):649-58.

34. Kassiri Z, Zhong J, Guo D, Basu R, Wang X, Liu PP, et al. Loss of angiotensinconverting enzyme 2 accelerates maladaptive left ventricular remodeling in response to myocardial infarction. Circ Heart Fail. 2009;2(5):446-55.

35. Yang JK, Lin SS, Ji XJ, Guo LM. Binding of Sars coronavirus to its receptor damages islets and causes acute diabetes. Acta Diabetol. 2010;47(3):193-9.

36. Oudit GY, Kassiri Z, Jiang C, Liu PP, Poutanen SM, Penninger JM, et al. Sarscoronavirus modulation of myocardial Ace 2 expression and inflammation in patients with Sars. Eur J Clin Invest. 2009;39(7):618-25.

37. Lukassen S, Lorenz Chua R, Trefzer T, Kahn NC, Schneider MA, Muley T, et al. Sars-Cov-2 receptor Ace2 and Tmprss 2 are primarily expressed in bronchial transient secretory cells. Embo j. 2020. https:/doi.org/10.15252/embj.20105114.

38. Yan D, Li G, Zhang Y, Liu Y. Angiotensin-converting enzyme 2 activation suppresses pulmonary vascular remodeling by inducing apoptosis through the hippo signaling pathway in rats with pulmonary arterial hypertension. Clin Exp Hypertens. 2019;41(6):589-98.

39. Prata LO, Rodrigues CR, Martins JM, Vasconcelos PC, Oliveira FM, Ferreira AJ, et al. Original research: Ace2 activator associated with physical exercise potentiates the reduction of pulmonary fibrosis. Exp Biol Med (Maywood). 2017;242(1):8-21.

40. Li G, Zhang H, Zhao L, Zhang Y, Yan D, Liu Y. Angiotensin-converting enzyme 2 activation ameliorates pulmonary endothelial dysfunction in rats with pulmonary arterial hypertension through mediating phosphorylation of endothelial nitric oxide synthase. J Am Soc Hypertens. 2017;11(12):842-52.

41. Yuan YM, Luo L, Guo Z, Yang M, Ye RS, Luo C. Activation of reninangiotensin-aldosterone system (Raas) in the lung of smoking-induced pulmonary arterial hypertension (Pah) rats. J Renin Angiotensin Aldosterone Syst. 2015;16(2):249-53.

42. Vuille-dit-Bille RN, Camargo SM, Emmenegger L, Sasse T, Kummer E, Jando J, et al. Human intestine luminal Ace2 and amino acid transporter expression increased by Ace-inhibitors. Amino Acids. 2015;47(4):693-705.

43. Gurwitz D. Angiotensin receptor blockers as tentative Sars-Cov-2 therapeutics. Drug Dev Res. 2020. https://doi.org/10.1002/ddr.21656.

44. Huang ML, Li X, Meng Y, Xiao B, Ma Q, Ying SS, et al. Upregulation of angiotensin-converting enzyme (Ace) 2 in hepatic fibrosis by Ace inhibitors. Clin Exp Pharmacol Physiol. 2010;37(1):e1-6.

45. Vaduganathan M, Vardeny O, Michel T, McMurray JJV, Pfeffer MA, Solomon SD. Renin-angiotensin-aldosterone system inhibitors in patients with Covid19. N. Engl J Med. 2020. https://doi.org/10.1056/NEJMsr2005760.

46. Fischer M, Baessler A, Schunkert $H$. Renin angiotensin system and gender differences in the cardiovascular system. Cardiovascular Research. 2002; 53(3):672-7

47. Chappell MC, Marshall AC, Alzayadneh EM, Shaltout HA, Diz DI. Update on the angiotensin converting enzyme 2-angiotensin (1-7)-Mas receptor axis: fetal programing, sex differences, and intracellular pathways. Front Endocrinol (Lausanne). 2014;4:201.
48. Regitz-Zagrosek $V$. Therapeutic implications of the gender-specific aspects of cardiovascular disease. Nat Rev Drug Discov. 2006;5(5):425-38.

49. Gupte M, Thatcher SE, Boustany-Kari CM, Shoemaker R, Yiannikouris F, Zhang $X$, et al. Angiotensin converting enzyme 2 contributes to sex differences in the development of obesity hypertension in C57bl/6 mice. Arterioscler Thromb Vasc Biol. 2012;32(6):1392-9.

50. Liu J, Ji H, Zheng W, Wu X, Zhu JJ, Arnold AP, et al. Sex differences in renal angiotensin converting enzyme 2 (Ace2) activity are 17beta-oestradioldependent and sex chromosome-independent. Biol Sex Differ. 2010;1(1):6.

51. Regitz-Zagrosek V, Oertelt-Prigione S, Seeland U, Hetzer R. Sex and gender differences in myocardial hypertrophy and heart failure. Circ J. 2010;74(7): 1265-73.

52. Seeland $U$, Regitz-Zagrosek V. Sex and gender differences in cardiovascular drug therapy. Handb Exp Pharmacol. 2012. https://doi.org/10.1007/978-3642-30726-3_11(214):211-236.

53. Bukowska A, Spiller L, Wolke C, Lendeckel U, Weinert S, Hoffmann J, et al. Protective regulation of the Ace2/Ace gene expression by estrogen in human atrial tissue from elderly men. Exp Biol Med (Maywood). 2017;242(14):1412-23.

54. Tipnis SR, Hooper NM, Hyde R, Karran E, Christie G, Turner AJ. A Human homolog of angiotensin-converting enzyme. Cloning and functional expression as a captopril-insensitive carboxypeptidase. J Biol Chem. 2000; 275(43):33238-43

55. White MC, Fleeman R, Arnold AC. Sex differences in the metabolic effects of the renin-angiotensin system. Biology of Sex Differences. 2019;10(1):31.

56. Dalpiaz PL, Lamas AZ, Caliman IF, Ribeiro RF Jr, Abreu GR, Moyses MR, et al. Sex hormones promote opposite effects on Ace and Ace2 activity, hypertrophy and cardiac contractility in spontaneously hypertensive rats. PLoS One. 2015;10(5):e0127515.

57. Santema BT, Ouwerkerk W, Tromp J, Sama IE, Ravera A, Regitz-Zagrosek V, et al. Identifying optimal doses of heart failure medications in men compared with women: a prospective, observational, cohort study. Lancet. 2019;394(10205):1254-63.

58. McMurray JJV, Jackson AM, Lam CSP, Redfield MM, Anand IS, Ge J, et al. Effects of sacubitril-valsartan versus valsartan in women compared with men with heart failure and preserved ejection fraction: insights from Paragon-Hf. Circulation. 2020;141(5):338-51.

59. Zhao Y, Zhao Z, Wang Y, Zhou Y, Ma Y, Zuo W. Single-cell Rna expression profiling of Ace2, the putative receptor of Wuhan 2019-Ncov. 2020;10.1101/ 2020.01.26.919985 \%J bioRxiv:2020.2001.2026.919985.

60. Kühne T, Mertins P, Kraus M. Smart study group. In; 2020.

61. Lucas JM, Heinlein C, Kim T, Hernandez SA, Malik MS, True LD, et al. The androgen-regulated protease Tmprss2 activates a proteolytic cascade involving components of the tumor microenvironment and promotes prostate cancer metastasis. 2014;4(11):1310-1325.

62. Lucas JM, True L, Hawley S, Matsumura M, Morrissey C, Vessella R, et al. The androgen-regulated type li serine protease Tmprss 2 is differentially expressed and mislocalized in prostate adenocarcinoma. J Pathol. 2008; 215(2):118-25.

63. Donaldson SH, Hirsh A, Li DC, Holloway G, Chao J, Boucher RC, et al. Regulation of the epithelial sodium channel by serine proteases in human airways. J Biol Chem. 2002;277(10):8338-45.

64. Tomlins SA, Rhodes DR, Perner S, Dhanasekaran SM, Mehra R, Sun X-W, et al. Recurrent Fusion of Tmprss 2 and Ets Transcription factor genes in prostate cancer. 2005;310(5748):644-648.

65. Klein SL, Huber S. Sex differences in susceptibility to viral infection. In: Klein SL, Roberts CW, editors. Sex Hormones and Immunity to Infection. Berlin: Springer-Verlag; 2009.

66. Griesbeck M, Altfeld M. Sex differences in the manifestations of Hiv-1 infection. In: Klein SL, Roberts CW, editors. Sex and Gender Differences in Infection and Treatments for Infectious Diseases. Cham: Springer International Publishing; 2015. p. 103-81.

67. Klein SL, Pekosz A, Passaretti C, Anker M, Olukoya P. (2010) Sex, gender and influenza in achieving gender equality and health equity.

68. Tsay PK, Tai DI, Chen YM, Yu CP, Wan SY, Shen YJ, et al. Impact of gender, viral transmission and aging in the prevalence of hepatitis $B$ surface antigen. Chang Gung Med J. 2009:32(2):155-64.

69. Chen CJ, Yang HI, Su J, Jen CL, You SL, Lu SN, et al. Risk of hepatocellular carcinoma across a biological gradient of serum hepatitis B virus DNA level. Jama. 2006;295(1):65-73.

70. El-Serag HB, Rudolph KL. Hepatocellular carcinoma: epidemiology and molecular carcinogenesis. Gastroenterology. 2007;132(7):2557-76. 
71. Boissier J, Chlichlia K, Digon Y, Ruppel A, Mone H. Preliminary study on sexrelated inflammatory reactions in mice infected with schistosoma mansoni. Parasitol Res. 2003;91(2):144-50.

72. Xia HJ, Zhang GH, Wang RR, Zheng YT. The influence of age and sex on the cell counts of peripheral blood leukocyte subpopulations in Chinese rhesus macaques. Cell Mol Immunol. 2009;6(6):433-40.

73. Melgert BN, Oriss TB, Qi Z, Dixon-McCarthy B, Geerlings M, Hylkema MN, et al. Macrophages: regulators of sex differences in asthma? Am J Respir Cell Mol Biol. 2010;42(5):595-603.

74. Pisitkun P, Deane JA, Difilippantonio MJ, Tarasenko T, Satterthwaite AB, Bolland S. Autoreactive B cell responses to Rna-related antigens due to Tr7 gene duplication. Science. 2006;312(5780):1669-72.

75. Fink AL, Engle $K$, Ursin RL, Tang WY, Klein SL. Biological sex affects vaccine efficacy and protection against influenza in mice. Proc Natl Acad Sci U S A 2018;115(49):12477-82

76. Souyris M, Cenac C, Azar P, Daviaud D, Canivet A, Grunenwald S, et al. TIr7 Escapes $X$ chromosome inactivation in immune cells. Sci Immunol. 2018 : 3(19).

77. Berghofer B, Frommer T, Haley G, Fink L, Bein G, Hackstein H. Tlr7 Ligands induce higher Ifn-alpha production in females. J Immunol. 2006;177(4): 2088-96.

78. Griesbeck M, Ziegler S, Laffont S, Smith N, Chauveau L, Tomezsko P, et al. Sex differences in plasmacytoid dendritic cell levels of Irf5 drive higher Ifnalpha production in women. J Immunol. 2015;195(11):5327-36.

79. Klein SL. Sex differences in prophylaxis and therapeutic treatments for viral diseases. In: Regitz-Zagrosek V, editor. Sex and Gender Differences in. Pharmacology: Springer; 2012

80. Klein $S L$, Jedlicka A, Pekosz A. The Xs and $Y$ of Immune responses to viral vaccines. Lancet Infect Dis. 2010;10(5):338-49.

81. Butterworth M, McClellan B, Allansmith M. Influence of sex in immunoglobulin levels. Nature. 1967;214(5094):1224-5.

82. Cook IF. Sexual dimorphism of humoral immunity with human vaccines. Vaccine. 2008;26(29-30):3551-5

83. Fan H, Dong G, Zhao G, Liu F, Yao G, Zhu Y, et al. Gender differences of B cell signature in healthy subjects underlie disparities in incidence and course of Sle related to estrogen. J Immunol Res. 2014;2014:814598.

84. Wikby A, Mansson IA, Johansson B, Strindhall J, Nilsson SE. The immune risk profile is associated with age and gender: findings from three Swedish population studies of individuals 20-100 years of age. Biogerontology. 2008; 9(5):299-308.

85. Villacres MC, Longmate J, Auge C, Diamond DJ. Predominant type $1 \mathrm{CmV}$ specific memory T-helper response in humans: evidence for gender differences in cytokine secretion. Hum Immunol. 2004:65(5):476-85.

86. Amadori A, Zamarchi R, De Silvestro G, Forza G, Cavatton G, Danieli GA, et al. Genetic control of the Cd4/Cd8 T-cell ratio in humans. Nat Med. 1995; 1(12):1279-83.

87. Das BR, Bhanushali AA, Khadapkar R, Jeswani KD, Bhavsar M, Dasqupta A. Reference ranges for lymphocyte subsets in adults from Western India: influence of sex, age and method of enumeration. Indian J Med Sci. 2008; 62(10):397-406.

88. Hewagama A, Patel D, Yarlagadda S, Strickland FM, Richardson BC. Stronger inflammatory/cytotoxic T-cell response in women identified by microarray analysis. Genes Immun. 2009;10(5):509-16.

89. Kovats S, Carreras E, Agrawal H. Sex steroid receptors in immune cells. In: Klein SL, Roberts CW, editors. Sex Hormones and Immunity to Infection. Berlin: Springer-Verlag; 2010. p. 53-92.

90. Arnold AP, Chen X. What does the "four core genotypes" mouse model tell us about sex differences in the brain and other tissues? Front Neuroendocrinol. 2009;30(1):1-9.

91. Poland GA, Ovsyannikova IG, Jacobson RM. Personalized vaccines: the emerging field of vaccinomics. Expert Opin Biol Ther. 2008;8(11):1659-67.

92. Barcena de Arellano ML, Pozdniakova S, Kuhl AA, Baczko I, Ladilov Y, RegitzZagrosek $V$. Sex differences in the aging human heart: decreased sirtuins, pro-inflammatory shift and reduced anti-oxidative defense. Aging (Albany NY). 2019;11(7):1918-33.

93. Leng SX, Margolick JB. Aging, sex, inflammation, frailty, and Cmv and Hiv infections. Cell Immunol. 2020;348:104024.

94. Gender. 2020. World Health Organisation. https://www.who.int/healthtopics/gender (Date accessed:02.04.2020).

95. Godin M. As cities around the world go on lockdown, victims of domestic violence look for a way out. Time 18/03/2020, 2020.
96. The impact of Covid-19 on women and children experiencing domestic abuse, and the life-saving services that support them. In. Women's Aid UK; 2020.

97. Global, regional, and national incidence, prevalence, and years lived with disability for 354 diseases and injuries for 195 countries and territories, 19902017: a systematic analysis for the global burden of disease study 2017. Lancet 2018;392(10159):1789-1858.

98. Heise L, Greene ME, Opper N, Stavropoulou M, Harper C, Nascimento M, et al. Gender inequality and restrictive gender norms: framing the challenges to health. Lancet. 2019;393(10189):2440-54.

99. Zhou F, Yu T, Du R, Fan G, Liu Y, Liu Z, et al. Clinical course and risk factors for mortality of adult inpatients with Covid-19 in Wuhan, China: a retrospective cohort study. Lancet. 2020;395(10229):1054-62.

100. Haider A, Bengs S, Luu J, Osto E, Siller-Matula JM, Muka T, et al. Sex and gender in cardiovascular medicine: presentation and outcomes of acute coronary syndrome. Eur Heart J. 2020;41(13):1328-36.

101. Delivered by women, led by men: a gender and equity analysis of the globa health and social workforce. 2019. World Health Organisation. https:/www. who.int/hrh/resources/health-observer24/en/ (Date accessed:02.04.2020).

102. Hawkins C, Chalamilla G, Okuma J, Spiegelman D, Hertzmark E, Aris E, et al. Sex differences in antiretroviral treatment outcomes among Hiv-infected adults in an urban Tanzanian setting. AIDS. 2011;25(9):1189-97.

103. Emery J, Pick N, Mills EJ, Cooper CL. Gender differences in clinical, immunological, and virological outcomes in highly active antiretroviral-treated Hiv-Hcv coinfected patients. Patient Prefer Adherence. 2010;4:97-103.

104. Lucas GM, Chaisson RE, Moore RD. Highly active antiretroviral therapy in a large urban clinic: risk factors for virologic failure and adverse drug reactions. Ann Intern Med. 1999;131(2):81-7.

105. Ofotokun I, Pomeroy C. Sex differences in adverse reactions to antiretroviral drugs. Top HIV Med. 2003;11(2):55-9.

106. Anderson PL, Kakuda TN, Kawle S, Fletcher CV. Antiviral dynamics and sex differences of zidovudine and lamivudine triphosphate concentrations in Hiv-infected individuals. AIDS. 2003;17(15):2159-68.

107. Ofotokun I, Chuck SK, Hitti JE. Antiretroviral pharmacokinetic profile: a review of sex differences. Gend Med. 2007;4(2):106-19.

108. Bersoff-Matcha SJ, Miller WC, Aberg JA, van Der Horst C, Hamrick HJ Jr, Powderly WG, et al. Sex differences in nevirapine rash. Clin Infect Dis. 2001; 32(1):124-9.

109. Andany N, Raboud JM, Walmsley S, Diong C, Rourke SB, Rueda S, et al. Ethnicity and gender differences in lipodystrophy of Hiv-positive individuals taking antiretroviral therapy in Ontario. Canada. HIV Clin Trials. 2011;12(2): 89-103.

110. Stanberry LR, Spruance SL, Cunningham AL, Bernstein DI, Mindel A, Sacks S, et al. Glycoprotein-D-adjuvant vaccine to prevent genital herpes. N Engl J Med. 2002;347(21):1652-61.

111. Straus SE, Corey L, Burke RL, Savarese B, Barnum G, Krause PR, et al. Placebocontrolled trial of vaccination with recombinant glycoprotein $D$ of herpes simplex virus type 2 for immunotherapy of genital herpes. Lancet. 1994; 343(8911):1460-3.

112. Zhang X, Castelli FA, Zhu X, Wu M, Maillere B, BenMohamed L. Genderdependent Hla-Dr-restricted epitopes identified from herpes simplex virus type 1 glycoprotein D. Clin Vaccine Immunol. 2008;15(9):1436-49.

113. Theng TS, Chan RK. Genital herpes in a sexually-transmitted infection clinic in Singapore: a 1-year retrospective study. Ann Acad Med Singapore. 2004; 33(2):200-3.

114. Reichman RC, Badger GJ, Guinan ME, Nahmias AJ, Keeney RE, Davis LG, et al. Topically administered acyclovir in the treatment of recurrent herpes simplex genitalis: a controlled trial. J Infect Dis. 1983;147(2):336-40.

115. Fang JW, Lai CL, Chung HT, Wu PC, Lau JY. Female children respond to recombinant hepatitis $B$ vaccine with a higher titre than male. J Trop Pediatr. 1994:40(2):104-7.

116. Hess G, Hingst V, Cseke J, Bock HL, Clemens R. Influence of vaccination schedules and host factors on antibody response following hepatitis $B$ vaccination. Eur J Clin Microbiol Infect Dis. 1992:11(4):334-40.

117. Morris CA, Oliver PR, Reynolds F, Selkon JB. Intradermal hepatitis B immunization with yeast-derived vaccine: serological response by sex and age. Epidemiol Infect. 1989;103(2):387-94

118. Zeeshan M, Jabeen K, Ali AN, Ali AW, Farooqui SZ, Mehraj V, et al. Evaluation of immune response to hepatitis $B$ vaccine in health care workers at a tertiary care hospital in Pakistan: an observational prospective study. BMC Infect Dis. 2007;7:120. 
119. Narciso-Schiavon JL, Schiavon Lde L, Carvalho-Filho RJ, Sampaio JP, Batah PN, Barbosa DV, et al. Gender influence on treatment of chronic hepatitis C genotype 1. Rev Soc Bras Med Trop. 2010;43(3):217-23.

120. Villa E, Karampatou A, Camma C, Di Leo A, Luongo M, Ferrari A, et al. Early menopause is associated with lack of response to antiviral therapy in women with chronic hepatitis C. Gastroenterology. 2011;140(3):818-29.

121. Yu JW, Sun LJ, Zhao YH, Kang P, Yan BZ. Impact of sex on virologic response rates in genotype 1 chronic hepatitis $C$ patients with peginterferon alpha-2a and ribavirin treatment. Int J Infect Dis. 2011;15(11): e740-6.

122. Engler RJ, Nelson MR, Klote MM, VanRaden MJ, Huang CY, Cox NJ, et al. Half- vs full-dose trivalent inactivated influenza vaccine (2004-2005): age, dose, and sex effects on immune responses. Arch Intern Med. 2008;168(22): 2405-14.

123. Cook IF, Barr I, Hartel G, Pond D, Hampson AW. Reactogenicity and immunogenicity of an inactivated influenza vaccine administered by intramuscular or subcutaneous injection in elderly adults. Vaccine. 2006; 24(13):2395-402.

124. Beyer WE, Palache AM, Kerstens R, Masurel N. Gender differences in loca and systemic reactions to inactivated influenza vaccine, established by a meta-analysis of fourteen independent studies. Eur J Clin Microbiol Infect Dis. 1996;15(1):65-70.

125. Nichol KL, Margolis KL, Lind A, Murdoch M, McFadden R, Hauge M, et al. Side effects associated with influenza vaccination in healthy working adults. A randomized, placebo-controlled trial. Arch Intern Med. 1996;156(14):1546-50.

126. Maltezou HC, Drakoulis N, Siahanidou T, Karalis V, Zervaki E, Dotsikas Y, et al. Safety and pharmacokinetics of oseltamivir for prophylaxis of neonates exposed to influenza H1n1. Pediatr Infect Dis J. 2011. https://doi.org/10. 1097/INF.0b013e3182472f28.

127. Blanchon T, Mentre F, Charlois-Ou C, Dornic Q, Mosnier A, Bouscambert M, et al. Factors associated with clinical and virological response in patients treated with oseltamivir or zanamivir for influenza a during the 2008-2009 winter. Clin Microbiol Infect. 2011. https://doi.org/10.1111/j.1469-0691.2011. 03751.x.

128. Potluri T, Fink AL, Sylvia KE, Dhakal S, Vermillion MS, Vom Steeg $L$, et al. Age-associated changes in the impact of sex steroids on influenza vaccine responses in males and females. NPJ Vaccines. 2019;4:29.

129. Wang M, Cao R, Zhang L, Yang X, Liu J, Xu M, et al. Remdesivir and chloroquine effectively inhibit the recently emerged novel coronavirus (2019-Ncov) in vitro. Cell Res. 2020;30(3):269-71.

130. Yao X, Ye F, Zhang M, Cui C, Huang B, Niu P, et al. In vitro antiviral activity and projection of optimized dosing design of hydroxychloroquine for the treatment of severe acute respiratory syndrome coronavirus 2 (Sars-Cov-2) Clin Infect Dis. 2020. https://doi.org/10.1093/cid/ciaa237.

131. Smith KY, Tierney C, Mollan K, Venuto CS, Budhathoki C, Ma Q, et al. Outcomes by sex following treatment initiation with atazanavir plus ritonavir or efavirenz with abacavir/lamivudine or tenofovir/emtricitabine. Clin Infect Dis. 2014;58(4):555-63.

132. Colson P, Rolain JM, Lagier JC, Brouqui P, Raoult D. Chloroquine and hydroxychloroquine as available weapons to fight Covid-19. Int J Antimicrob Agents. 2020. https://doi.org/10.1016/j.jjantimicag.2020.105932: 105932.

133. Poluzzi E, Raschi E, Motola D, Moretti U, De Ponti F. Antimicrobials and the risk of torsades de pointes: the contribution from data mining of the Us Fda adverse event reporting system. Drug Saf. 2010;33(4):303-14.

134. Giudicessi JR, Noseworthy PA, Friedman PA, Ackerman MJ. Urgent guidance for navigating and circumventing the Qtc prolonging and torsadogenic potential of possible pharmacotherapies for Covid-19 Mayo Clin Proc 2020;95.

135. Chen CY, Wang FL, Lin CC. Chronic hydroxychloroquine use associated with Qt prolongation and refractory ventricular arrhythmia. Clin Toxicol (Phila). 2006;44(2):173-5.

136. Abi-Gerges N, Philp K, Pollard C, Wakefield I, Hammond TG, Valentin JP. Sex differences in ventricular repolarization: from cardiac electrophysiology to torsades de pointes. Fundam Clin Pharmacol. 2004;18(2):139-51.

137. Regitz-Zagrosek V, Oertelt-Prigione S, Prescott E, Franconi F, Gerdts E, ForystLudwig A, et al. Gender in cardiovascular diseases: impact on clinical manifestations, management, and outcomes. Eur Heart J. 2016;37(1):24-34.

138. Grundmann M. Effects of chloroquine on the adrenocortical function. lii. Sex differences in concentrations of cholesterol and ascorbic acid in the suprarenal gland after a single administration of chloroquine in the rat. Arzneimittelforschung. 1977;27(4):801-4.
139. Nicola WG, Khayria MI, Osfor MM. Plasma testosterone level and the male genital system after chloroquine therapy. Boll Chim Farm. 1997;136(1):3943

140. Clinckemalie L, Spans L, Dubois V, Laurent M, Helsen C, Joniau S, et al. Androgen regulation of the Tmprss 2 gene and the effect of a Snp in an androgen response element. Molecular endocrinology (Baltimore, Md.). 2013;27(12):2028-40

141. Shiau S, Kuhn L, Strehlau R, Martens L, Mcllleron H, Meredith S, et al. Sex Differences in responses to antiretroviral treatment in South African Hivinfected children on ritonavir-boosted lopinavir- and nevirapine-based treatment. BMC Pediatr. 2014:14:39.

142. Umeh OC, Currier JS, Park JG, Cramer Y, Hermes AE, Fletcher CV. Sex differences in lopinavir and ritonavir pharmacokinetics among Hiv-infected women and men. J Clin Pharmacol. 2011;51(12):1665-73.

143. Tardif JC, Kouz S, Waters DD, Bertrand OF, Diaz R, Maggioni AP, et al. Efficacy and safety of low-dose colchicine after myocardial infarction. N Engl J Med. 2019;381(26):2497-505.

144. Wiesenfeld PL, Garthoff LH, Sobotka TJ, Suagee JK, Barton CN. Acute oral toxicity of colchicine in rats: effects of gender, vehicle matrix and preexposure to lipopolysaccharide. J Appl Toxicol. 2007;27(5):421-33.

145. Davies SE, Bennett B. A gendered human rights analysis of ebola and zika: locating gender in global health emergencies. International Affairs. 2016; 92(5):1041-60

146. Harman S. Ebola, Gender and conspicuously invisible women in global health governance. Third World Quarterly. 2016;37(3):524-41.

147. Sochas L, Channon AA, Nam S. Counting indirect crisis-related deaths in the context of a low-resilience health system: the case of maternal and neonatal health during the ebola epidemic in Sierra Leone. Health Policy Plan. 2017;32(suppl_3):iii32-9.

148. Klein SL, Passaretti C, Anker M, Olukoya P, Pekosz A. The impact of sex, gender and pregnancy on 2009 H1n1 disease. Biol Sex Differ. 2010;1(1):5.

149. Ko CJ, Huang CC, Lin HY, Juan CP, Lan SW, Shyu HY, et al. Androgeninduced Tmprss2 activates matriptase and promotes extracellular matrix degradation, prostate cancer cell invasion, tumor growth, and metastasis. Cancer Res. 2015;75(14):2949-60.

\section{Publisher's Note}

Springer Nature remains neutral with regard to jurisdictional claims in published maps and institutional affiliations.

Ready to submit your research? Choose BMC and benefit from:

- fast, convenient online submission

- thorough peer review by experienced researchers in your field

- rapid publication on acceptance

- support for research data, including large and complex data types

- gold Open Access which fosters wider collaboration and increased citations

- maximum visibility for your research: over $100 \mathrm{M}$ website views per year

At $\mathrm{BMC}$, research is always in progress.

Learn more biomedcentral.com/submissions 